\title{
Inheritance of IVSI-I Mutation Assures 158 (C-T) XmnI Polymorphism in Thalassemia Intermedia
}

\author{
Shakila ASHRAF ${ }^{1}$, Moinuddin MOINUDDIN ${ }^{2}$ \\ ${ }^{1}$ Sultan Qaboos University, Department of Haematology, Muscat, OMAN \\ ${ }^{2}$ Baqai Medical University, Department of Hematology, Karachi, PAKISTAN
}

\begin{abstract}
Thalassemia intermedia lies between asymptomatic $\beta$-thalassemia carrier state to severe thalassemia Major. Xmnl polymorphism is one of the modifying factors of intermedia phenotype. This study intendeds to determine the frequency of Xmn-I polymorphism and its association with different beta chain mutations that would contribute towards the phenotype. 100 whole blood samples of thalassemia intermedia patients were tested for the common beta chain mutations found in Pakistan and then tested for Xmn-I polymorphism. The most common mutation identified in these patients was IVSI-5. Xmn-I polymorphism was found in $79 \%$ of the patients, 36\% being homozygous and $43 \%$ being heterozygous. Xmn-I polymorphism was found in $84.7 \%$ of the samples with IVSI-5 mutation, $52.1 \%$ of Fr $8-9,45 \%$ of Cap+1, $85.7 \%$ of Cd30, $91.66 \%$ of $\mathrm{HbE}$, and $33.3 \%$ of the samples with del619 mutation. Whereas $\delta \beta, \mathrm{HbS}$, IVSI-I showed $100 \%$ positivity for Xmn-I polymorphism. The age of start of transfusion was $3-9$ years and had high hemoglobin $\mathrm{F}$ levels. All the samples with IVSI-I mutation were homozygous (+/+) for Xmn-I polymorphism. Thus a firm linkage between the Xmnl polymorphism and IVSI-I mutation is suggested and that IVSI-I mutation always accompany homozygosity of Xmn-I polymorphism and the coinheritance of the two mutations will lead to a milder phenotype.
\end{abstract}

Keywords: Thalassemia intermedia, Xmn-I polymorphism, IVSI-I mutation, HbS, $\delta \beta$ thalassemia

\section{ÖZET}

Talasemi İntermediada IVSI-I Mutasyon Kalıtımı, 158 (C-T) Xmn-I Polimorfizmini Sağlar

Talasemi intermedia, asemptomatik $\beta$-talasemi taşıyıcılık durumu ile ciddi talasemi major arasındadır. İntermediate fenotipte hastalığı modifiye eden faktörlerden biri Xmn-I polimorfizmidir. Bu çalışamada talasemi intermedia hasta grubunda, Xmn-I polimorfizmi sıklığını ve farklı beta zincir mutasyonları ile ilişkisini ve fenotipe olan katkısını incelemeyi amaçladık. Pakistan' da Talasemi intermediate hastası olan 100 kişiden kan örnekleri alındı ve bu örneklerde beta zincir mutasyonu ve Xmn-I polimorfizmi çalışıldı. Bu hastalarda tespit edilen en sık mutasyon IVSI-5 idi. Xmn-I polimorfizmi \%79 hastada bulundu; bunların \%36'sı homozigot iken \%43'ü ise heterozigot idi. IVSI-5 mutasyonlarında Xmn-I polimorfizmi \%84.7 oranında saptanırken, Fr 8-9'da \%52.1, Cap+1'de \%45 Cd30'da \%85.7, HbE, \%91.66'da del619 mutasyonu olanlarda ise \% 33.3 oranında saptandı. Ancak $\delta \beta$, HbS, IVSI-l'lı grupta Xmn-I polimorfizmi \%100 pozitif idi. Bu hastaların transfüzyona bașlama yașı 3-9 yaș arasında ve yüksek hemoglobin F seviyelerine sahip idiler. IVSI-I mutasyonu olan hastaların hepsinde homozigot (+/+) Xmn-I polimorfizmi var idi. IVSI-I mutasyonu ve Xmn-I polimorfizmi arasındaki önemli ilişkiye dayanarak şunu önerebiliriz; IVSI-I mutasyonu herzaman Xmn-I polimorfizmine eşlik etmektedir. Bu eş zamanlı mutasyonun varlığı daha hafif seyirli fenotipe neden olmaktadır.

Anahtar Kelimeler: Talasemi intermedia, Xmn-I polimorfizmi, IVSI-I mutasyonu, HbS, $\delta \beta$ talasemi 


\section{INTRODUCTION}

Thalassemia intermedia describes the condition with clinical manifestations that is between asymptomatic $\beta$-thalassemia carrier to severe thalassemia Major. ${ }^{1}$ This significant clinical heterogeneity fallout from different genetic determinants influencing the clinical outcome of the disease..$^{2-6}$ The underlying genetic diversity can best be enlightened by primary, secondary, and tertiary genetic modifiers. ${ }^{7}$ High percentage of XmnI polymorphism has been found in thalassemia intermedia patients. ${ }^{8} \mathrm{Xmn}-\mathrm{I}$ $\mathrm{G} \gamma$ polymorphism in association with homozygous $\beta^{\circ}$-thalassemia is one of the renowned phenotype modifying factors. ${ }^{3,9-11} \mathrm{Xmn}-\mathrm{I}$ polymorphism is heterogeneously distributed in different parts of the world. ${ }^{12,13}$ However the molecular mechanisms describing the effects of beta thalassemia mutations on the distribution of XmnI polymorphism are not well outline. This study intendeds to determine the frequency of Xmn-I polymorphism and its association with different beta chain mutations that would determine the contribution towards the milder phenotype.

\section{PATIENTS AND METHODS}

Whole blood samples of 100 thalassemia Intermedia patients were collected. The study was approved by the Institutional Ethics Committee. An informed consent was taken from the patients before sample collection. Information of each patient regarding their age, sex, ethnic group, commencement of transfusion and clinical appearance was noted at the time of sample collection. The criteria for the inclusion of the patients for this study was, that the patient be known thalassemic, age at start of transfusion was more than three years and the interval between the transfusion was at least one month.

Complete blood counts of the samples were carried out. The samples were then tested for the common beta chain mutations found in Pakistan by multiplex amplified refractory mutation system PCR. Samples were then tested for Xmn-I polymorphism. In order to demonstrate this polymorphism, a $641 \mathrm{bp}$ fragment of DNA flanking the polymorphism was amplified using the following primers.

\begin{tabular}{|lcr|}
\hline \multicolumn{2}{|l|}{ Table 1. Xmn-I G $\gamma$ Genotype in TI Patients } \\
\hline Xmn-I genotype & Frequency & $\begin{array}{r}\text { Cumulative } \\
\text { percentage }\end{array}$ \\
$-/+$ & 43 & 43 \\
$+/+$ & 36 & 79 \\
$-/-$ & 21 & 0 \\
Total & 100 & \\
\hline
\end{tabular}

\section{5' - GAA CTT AAG AGA TAA TGG CCT AA 5' - ATG ACC CAT GGC GTC TGG ACT AG}

The reaction mixture was prepared by adding 20 $\mu 1$ of buffer, $1 \mu \mathrm{l}$ of primer, $2 \mu \mathrm{l}$ of DNA and $0.1 \mu \mathrm{l}$ of Taq. The PCR conditions for the RFLP protocol was $94^{\circ} \mathrm{C}$ for 1 minute of denaturation , annealing at $60^{\circ} \mathrm{C}$ for 1 minute, extension at $72^{\circ} \mathrm{C}$ for $1 \mathrm{~min}$ ute and 3 minutes of final extension at $72^{\circ} \mathrm{C}$. Numbers of cycles carried out were 30 . Amplified fragment was digested with 10 units of enzyme P $d m$-I (Fermentus) at $37^{\circ} \mathrm{C}$ overnight and the results were recorded after electrophoresis on 6\% Acrylamide gel. The calculations were carried out using SPSS version 17.

\section{RESULTS}

Xmn-I polymorphism was located in $79 \%$ of the samples, $36 \%$ of the samples were homozygous $(+/+), 43 \%$ were heterozygous (-/+) and $21 \%$ were negative for Xmn-I polymorphism (Table 1). IVSI5 mutation declared $92 \%$ of the alleles, Fr 8-9 was $23 \%$ and Cap $+120 \%$ of the total alleles. IVSI-I was found in $15 \%$ of the patients and $\delta \beta$ in $10 \%$ of the patients, both the mutations showed $100 \%$ positivity for homozygous Xmn-I polymorphism $(+/+) . \mathrm{HbS}$ was found in $6 \%$ of the samples, out of which 4 were heterozygous $(-/+)$ and 2 were homozygous $(+/+)$ for Xmn-I polymorphism. Percentages of the rest are given in Table $2.52 \%$ of the samples were homozygous and $46 \%$ of the samples were heterozygous for the beta chain mutations. IVSI-5 / IVSI-5 genotype was found in 29\% of the patients, out of which $13 \%$ were homozygous, $12 \%$ were heterozygous, and $4 \%$ were negative 


\begin{tabular}{|c|c|c|c|c|c|}
\hline \multirow[b]{2}{*}{ Mutation } & \multirow[b]{2}{*}{ Number } & \multicolumn{3}{|c|}{ Xmn-I polymorphism } & \multirow[b]{2}{*}{ Xmn-I positivity } \\
\hline & & $-/-$ & $-/+$ & $+1+$ & \\
\hline IVSI-5 & 92 & 14 & 43 & 35 & $78(84.7)$ \\
\hline Fr 8-9 & 23 & 11 & 12 & 0 & $12(52.1)$ \\
\hline Сар+1 & 20 & 11 & 7 & 2 & $9(45)$ \\
\hline IVSI-I & 15 & 0 & 0 & 15 & $15(100)$ \\
\hline Cd30 & 14 & 2 & 6 & 6 & $12(85.7)$ \\
\hline $\mathrm{HbE}$ & 12 & 1 & 6 & 5 & $11(91.6)$ \\
\hline$\delta \beta$ & 10 & 0 & 0 & 10 & $10(100)$ \\
\hline $\mathrm{HbS}$ & 6 & 0 & 4 & 2 & $6(100)$ \\
\hline Del 619 & 3 & 2 & 1 & 0 & $1(33.3)$ \\
\hline Cd15 & 2 & 0 & 2 & 0 & $2(100)$ \\
\hline Fr 41- 42 & 1 & 0 & 1 & 0 & $1(100)$ \\
\hline Fr16 & 1 & 1 & 0 & 0 & 0 \\
\hline Unknown & 1 & 0 & 1 & 0 & $1(100)$ \\
\hline Total & 200 & & & & \\
\hline
\end{tabular}

for Xmn-I polymorphism. The genotype IVSI-5 / Cap +1 was found in 11 percent of the patients under study, out of which $2 \%$ were homozygous, $5 \%$ were heterozygous and $4 \%$ were negative for Xmn-I polymorphism (Table 3 ).

Xmn-I polymorphism was found in $79 \%$ of the patients (Table 2). 52\% of the samples were homozygous and $46 \%$ of the samples were compound heterozygous for beta chain mutation.

\section{DISCUSSION}

The most common mutation identified in this group of thalassemia intermedia patients was IVSI-5. A strong link was observed between IVSI-I and Xmn-I polymorphism. All the samples with IVSI-I mutation were homozygous for Xmn-I polymorphism. The age at start of transfusion was 3-9 years and had high hemoglobin F levels. Five of the samples being homozygous for the IVSI-I mutation
(IVSI-I/IVSI-I) were homozygous for Xmn-I polymorphism and five of the samples were compound heterozygous for IVSI-I / IVSI-5 mutations, out of which 3 had -/+ and 2 had +/+ Xmn-I polymorphism genotype (Table 3) but none of them was Xmn-I polymorphism negative. Such a strong association of the Xmn-I and IVSI-I suggests a possible linkage between the two molecular defects. Thus suggesting the assurance of coexistence of IVSII mutation with Xmn-I polymorphism and would pedestal the appearance of thalassemia intermedia phenotype. But the molecular defect describing their coinheritance is yet to be investigated.

$\mathrm{Xmn}-\mathrm{I}$ gene polymorphism is known to be one of the main phenotype modifying factors of $\beta$-thalassemia. ${ }^{14} \mathrm{C}$-T polymorphism at 158 base pair upstream Gc gene ( XmnI polymorphism) may affect the haemoglobin $\mathrm{F}$ production leading to remodeling of thalassemia phenotype. ${ }^{12,15}$ It has been documented that the presence of Xmn-1(G) gamma 
International Journal of Hematology and Oncology

\begin{tabular}{|c|c|c|c|c|c|c|c|c|c|}
\hline \multirow{2}{*}{$\begin{array}{l}\text { Mutations } \\
\text { identified }\end{array}$} & \multicolumn{3}{|c|}{ Xmn-I } & \multirow[t]{2}{*}{ Total } & \multirow{2}{*}{$\begin{array}{l}\text { Mutations } \\
\text { identified }\end{array}$} & \multicolumn{3}{|c|}{ Xmn-I } & \multirow[t]{2}{*}{ Total } \\
\hline & $+/+$ & $-/+$ & $-/-$ & & & $+/+$ & $-/+$ & $-/-$ & \\
\hline IVSI-5 / IVSI-5 & 13 & 12 & 4 & 29 & IVSI-5 / Cap+1 & 2 & 5 & 4 & 11 \\
\hline Fr 8-9 / Fr 8-9 & & 4 & 3 & 7 & IVSI-5 / HbE & 3 & 5 & 1 & 9 \\
\hline IVSI-I / IVSI-I & 5 & & & 5 & IVSI-5 / IVSI-I & 2 & 3 & & 5 \\
\hline$\delta \beta$ & 5 & & & 5 & Fr 8-9 / Cap+1 & & 1 & 3 & 4 \\
\hline Cd30 / Cd30 & 3 & 1 & & 4 & IVSI-5 / HbS & 2 & 1 & & 3 \\
\hline Cd15 / Cd15 & & 1 & & 1 & Del 619 / Cap+1 & & & 2 & 2 \\
\hline $\mathrm{HbE} / \mathrm{HbE}$ & 1 & & & 1 & Fr 8-9 / Cd30 & & 1 & 1 & 2 \\
\hline Total & & & & 52 & Cap+1 / HbS & & 1 & & 1 \\
\hline \multirow[t]{10}{*}{ Fr 8-9/ Unknown } & & 1 & & 1 & Cd30 / Cap+1 & & & 1 & 1 \\
\hline & & & & & $\mathrm{Cd} 30 / \mathrm{HbE}$ & & 1 & & 1 \\
\hline & & & & & $\mathrm{Cd} 30 / \mathrm{HbS}$ & & 1 & & 1 \\
\hline & & & & & Fr 8-9/ HbE & & 1 & & 1 \\
\hline & & & & & Fr16 / Cap+1 & & & 1 & 1 \\
\hline & & & & & IVSI-5 / Cd30 & & 1 & & 1 \\
\hline & & & & & IVSI-5 / Del 619 & & 1 & & 1 \\
\hline & & & & & IVSI-5 / Fr 41-42 & & 1 & & 1 \\
\hline & & & & & IVSI-5 / Fr 8-9 & & & 1 & 1 \\
\hline & & & & & Total & & & & 46 \\
\hline
\end{tabular}

polymorphism with IVS1-1(G- T) results in late clinical presentation and is associated with variable progress with hydroxyurea therapy. ${ }^{16,17}$ IVSII is an RNA splicing mutation. ${ }^{18}$ Mutations that affect either of the invariant dinucleotides in the splice junction completely abolish normal splicing and produce the phenotype of $\beta^{\circ}$ thalassemia. Genes bearing these mutations appear to transcribe normally and, although some alternative splicing occurs using "cryptic" donor or acceptor sites, the misspliced mRNA do not translate into functional $\beta$ globin. Thus mutations at splice junctions of exon 1/IVS1, IVS1/exon 2 and exon 2/IVS2 all abolish normal splicing causing a $\beta^{\circ}$ thalassemia phenotype. ${ }^{19,20}$ These patients inspite of having the mutations that lead to a $\beta^{\circ}$ thalassemia presented with milder phenotype. Thus the milder phenotype might be a result of the co inheritance of the XmnI polymorphism.

In this study all the 6 patients with $\mathrm{HbS}$ were positive for Xmn-I polymorphism either in homozygous or heterozygous form. It has been reported that $\mathrm{G} \gamma$-polymorphism increases the production of $\mathrm{Hb}-\mathrm{F}$, reducing the severity of the disease..$^{15,21-23}$ Thus envisage that presentation of $\mathrm{HbS}$ with the support of Xmn-I polymorphism presents in thalassemia intermedia phenotype.

Similar association was demonstrated between ${ }^{\mathrm{G}} \gamma$ $\left({ }^{\mathrm{A}} \gamma \delta \beta\right)^{\circ}$ and $\mathrm{XmnI}$ polymorphism in this study where 5 of the samples were homozygous for $\mathrm{G} \gamma$ $\left.\left({ }^{\mathrm{A}} \gamma \delta \beta\right)^{\circ}\right)$ mutations and all were also homozygous 
for XmnI polymorphism. This is in accordance of a study by Ahmed S 2005. Thus XmnI polymorphism is linked to completely deleted beta gene as in the case of $\delta \beta$ thalassaemia where it can be assumed that the loss of regulatory regions for the c-genes, the rearrangement of the b-gene complex that brings enhancer sequences close to the Gc-globin gene promoter, and the loss of competition for a common locus control region (LCR) between the c-, d-,and the b-gene promoters may be involved. ${ }^{15}$

The aptitude to predict phenotype from genotype has important implication for the screening of beta-thalassemia carriers, for genetic counseling and prenatal diagnosis and for setting up an appropriate treatment regimen. Therefore it is important to have genotype analysis to establish an early diagnosis of mild beta-thalassemia. Nevertheless because of the genetic and environmental modifying factors it is still a challenge to predict thalassemia intermedia phenotype. ${ }^{21}$

\section{Conclusion}

As a conclusion our results strongly suggest a firm linkage between the XmnI Ggpolymorphism and IVSI-I mutation. Presence of IVSI-I mutation declares homozygosity of Xmn-I polymorphism and the coinheritance of these mutations leads to the intermedia phenotype.

Homozygous $\left.\mathrm{G} \gamma(\mathrm{A} \gamma \delta \beta)^{\circ}\right)$ and $\mathrm{HbS}$ also shows strong association to Xmn-I polymorphism. Thus it is reasonable to speculate that we have contained the principal genetic defect in this illustration and that it leads to the observed phenotype.

\section{Acknowledgments}

I would like to extend my deepest gratitude to Gen. Suhaib Ahmed of Armed forces institute of pathology, Rawalpindi for his marvelous supervision in the study. Thanks are also due for the technical staff of the institute for their tremendous support. The research work was partially funded by baqai institute of hematology, PNS shifa Karachi, Armed forces institute of hematology Rawalpindi plus including some self funds.

\section{Funding source}

The project was self supported but partially funded by Baqai Medical University, Armed forces institute of hematology, Rawalpindi and PNS shifa $\mathrm{Ka}$ rachi.

\section{REFERENCES}

1. Thi Khanh TN, Philippe J, Claire Bl, et al. The Xmnl Gy polymorphism influences hemoglobin $F$ synthesis contrary to BCL11A and HBS1L-MYB SNPs in a cohort of $57 \beta$-thalassemia intermedia patients. Blood Cells Mol Dis 45: 124-127, 2010.

2. Anthony $H$, Paul $T$, Amr R, et al. $\beta$-Thalassemia Intermedia: $A$ Bird's-Eye View. Turk J Hematol 31: 5-16, 2014.

3. Anzel B, Erol OA. Frequency of Gy-globin promoter -158 (C>T) Xmn Ipolymorphism in Denizli, Turkey. Int J Physic Sci 7: 1927-1931, 2012.

4. Wanqun C, Xinhua Z, Xuan S, et al. The molecular basis of beta-thalassemia intermedia in southern China: genotypic heterogeneity and phenotypic diversity. BMC Med Genet 11: 31, 2010.

5. Rachid H, Hani M, Ali T. Paraspinal extramedullary hematopoiesis in patients with thalassemia intermedia. Eur Spine $\mathrm{J}$ 19: 871-878, 2010.

6. Ali T, Hussain NI, Maria D, Cappellini A. Thalassemia intermedia: Revisited. Blood Cells Mol Dis 37: 12-20, 2006.

7. Renzo G. Recent advances in the molecular understanding of non-transfusion-dependent Thalassemia. Blood Rev 26: 7-11, 2012.

8. Tamoor BH, Suhaib A, Jaleel A, Syed Kazim AK. Xmnl Polymorphism and disease severity in patients with beta thalassemia from northern Pakistan. J Ayub Med Coll Abbottabad 27: 13-16, 2015.

9. Maryam Neishabury N, Azita A, Hossein N. Frequency of Positive Xmnl Gy polymorphism and coinheritance of common alpha thalassemia mutations do not show statistically significant difference between thalassemia major and intermedia cases with homozygous IVSII-1 mutation. Blood Cells Mol Dis 44: 95-99, 2010.

10. Amel Haj K, Madeleine M, Sandrine L, et al. Xmn I polymorphism associated with concomitant activation of $\mathrm{G} \gamma$ and $\mathrm{A} \gamma$ globin gene transcription on a $\beta^{\circ}$-thalassemia chromosome. Blood Cells Mol Dis 46: 133-138, 2011.

11. Shawky RM, Kamal TM. Thalassemia intermedia: An overview. The Egyptian Journal of Medical Human Genetics 13: 245255, 2012.

12. Nadir A, Muhammad A, Saleem Ahmed K, et al. Frequency of Gc-globin promoter -158 (C>T) Xmnl polymorphism in patients with homozygous/compound heterozygous beta thalassaemia. Hematol Oncol Stem Cell Ther 8: 10-15, 2015. 
International Journal of Hematology and Oncology

13. Lalana N, Supan F, Goonnapa F, et al. Molecular, hematological and clinical aspects of thalassemia major and thalassemia intermedia associated with $\mathrm{Hb}$ E- $\beta$-thalassemia in Northeast Thailand. Blood Cells Mol Dis 42: 32-35, 2009.

14. Said F, Abdel-Salam A. Xmnl polymorphism: Relation to $\beta$-thalassemia phenotype and genotype in Egyptian Children. Egypt J Med Hum Genet 12: 2014. http://dx.doi. org/10.1016/j.ejmhg.2014.12.005

15. Ahmed S, Anwar M. Xmnl Ggamma-polymorphism in six unrelated Pakistani families with Inv/ Del Ggamma (Agammadeltabeta) degrees delta beta thalassemia. Am J Hematol 80: 303-305, 2005.

16. Sharma N, Das R, Kaur J, et al. Evaluation of the genetic basis of phenotypic heterogeneity in north Indian patients with thalassemia major. Eur J Haematol 84: 531-517, 2010.

17. Fadwa S, Amina AS. Xmnl polymorphism: Relation to $\beta$-thalassemia phenotype and genotype in Egyptian Children. Egypt J Med Hum Genet 16: 123-127, 2015.

18. Hamid G, Mohammad P, Bahaoddin S, Behnaz A. Wide Spectrum of Mutations in the Beta-Globin Gene Causing Beta-Thalassemia Major in Southwest Iran. Iranian J Pediatr Soc 2: 4-8, 2010.

19. Ho PJ, Thein SL. Gene regulation and deregulation: a $\beta$ globin perspective. Blood Rev 14: 78-93, 2000.

20. Stuart HO, Sabra CG, Rachel LH. Mutation in an intervening sequence splice junction in man $\alpha$-thalassemia/gene cloning/ DNA sequence analysis/RNA processing/stable RNAs. Proc Natl Acad Sci USA 78: 5041-5045, 1981.
21. Ali T, Hussain I, Maria DC. Thalassemia intermedia: Revisited. Blood Cells Mol Dis 37: 12-20, 2006.

22. Dabke P, Colah RB, Ghosh K, Nadkarni A. Effect of a group of genetic markers around the 5 regulatory regions of the $\beta$ globin gene cluster linked to high $\mathrm{HbF}$ on the clinical severity of $\beta$ thalassemia. Blood Cells Mol Dis 1: 156-160, 2013.

23. Dadheech S, Suman J, Madhulatha D, et al. Association of Xmn1 $2158 \mathrm{cG}$ variant with severity and $\mathrm{HbF}$ levels in $\beta$-thalassemia major and sickle cell anaemia. Mol Biol Rep 41: 3331-3337, 2014.

\section{Correspondence}

Dr. Shakila ASHRAF

P. O Box 38. Al-khodh

MUSCAT / OMAN

Tel: 0096897158837

Fax: 0096824144887

e-mail: shakila_ashraf@hotmail.com shakila@squ.edu.om 